\title{
The use of biologically active substances in the composition of organic fertilizers in the cultivation of tomatoes in greenhouses
}

\author{
Maria Selivanova1 ${ }^{*}$, Timur Aysanov ${ }^{1}$, Elena Romanenko ${ }^{1}$, Elena Mironova ${ }^{1}$, Natalia \\ Esaulko $^{1}$, and Maria German ${ }^{1}$ \\ ${ }^{1}$ Stavropol State Agrarian University, lane Zootechnical 12, Stavropol, 355017, Russia
}

\begin{abstract}
The purpose of the research is to study the effect of biologically active substances in organic fertilizers on the productivity of tomato Sherami F1 in a winter greenhouse. The production experience was laid in a winter glazed greenhouse, which is located in the sixth light zone.The objects of research were cherry tomato plants Sherami F1, organic fertilizers 5AP, Maxifol Rutfarm, Nutrimir 4-4-10, Quick-Link. In the experiment, the average plant growth per week, the height of the plants, the number of leaves, the number of brushes collected and the average weight of the fetus, the chemical composition of the plants and yield were determined. The largest growth in a week and the tallest plants were obtained with Quick-Link; the most brushes collected and the largest fruits - when applying fertilizer 5AP. The use of organic fertilizers contributed to the better absorption of macronutrients by tomato plants from a nutrient solution: the content of nitrogen, phosphorus and potassium in the leaves and fruits increased relative to the control. When using biologically active substances in organomineral fertilizers, tomato productivity increased by $1.1-2.7 \mathrm{~kg} / \mathrm{m} 2$ compared to the control, and the biochemical composition of the fruits improved.
\end{abstract}

\section{Introduction}

Over the past decade, greenhouse growing in the world has transformed into a highly industrialized agricultural sector. Under optimal conditions of microclimate and nutrition, which are created in greenhouse complexes using modern equipment, it is possible to obtain a stable high productivity of vegetable crops.

Tomato is an important vegetable crop that is widely grown throughout the world $[1,2]$. Tomato is the second leading greenhouse growing culture after cucumber. The high nutritional value of tomato fruits is confirmed by stable demand. The increase in greenhouse production is ensured by increasing productivity and expansion the area of greenhouses. It is possible to increase tomato productivity with the help of various agricultural techniques: additional illumination of plants [3], irrigation mode [4], plant protection against diseases [5], and more.

\footnotetext{
*Corresponding author: seliwanowa86@mail.ru
} 
Mineral nutrition of greenhouse crops is an effective method of regulating the growth and development of plants [6, 7]. The use of fertilizers containing macro-, microelements and biologically active substances in the tomato growing technology ensures intensification of metabolic processes in plants, increases stress resistance to adverse factors and ultimately ensures high productivity. A number of foreign scientific works cite data on the experience of using biologically active substances (salicylic acid, epi-brassinolide) and nontraditional nutrients (silicon) for a tomato plant and show a high efficiency of increasing crop productivity depending on these techniques $[8,9]$.

\section{Materials and methods}

The purpose of the research is to study the effect of biologically active substances in organomineral fertilizers on the productivity of tomato Sherami F1 in a winter greenhouse. The studies were conducted during the extended turnover of 2019 in a greenhouse ground. The production experience was laid in a winter glazed greenhouse, which according to the level of solar radiation per unit surface is located in the sixth light zone (Stavropol Territory). In the greenhouse, using the climate computer program, the microclimate is automatically regulated using the climate system, which is created with the help of heating systems, additional illumination, carbon dioxide top-dressing, additional air humidification, drip irrigation, mineral nutrition and additional plant additional illumination. Coconut fiber was used as a substrate.

The objects of research were tomato Sherami F1, organomineral fertilizers 5AP, Maxifol Rutfarm, Nutrimir 4-4-10, Quick-Link.

Sherami F1 (Originator - Rijk Zwaan, Netherlands) - indeterminate hybrid of tomato for growing in greenhouse ground. The hybrid belongs to the group of cherry tomatoes for piece collection. The fruit is round in shape, weighing up to $16 \mathrm{~g}$, dense, does not crack. The plant is open, powerful, has good fruit set, short internodes.

$5 A P(5 \& U P)$ (Manufacturer - ITALPOLLINA Group, Italy) - organomineral fertilizer in liquid form, containing potassium, nitrogen in the organic and amide form, phosphorus, biologically active substances - amino acids, peptides and organic substances. Fertilizer increases the absorption of nutrients by plants, has anti-stress properties, a biostimulating effect, and enhances the activity of soil microflora (substrate).

Maxifol Rutfarm (Manufacturer - AgroMaster, Russia) - organomineral fertilizer containing potassium, nitrogen in an organic and amide form, zinc chelate and biological active substances (batin, cytokinin, auxin, giberbilin, alginic acid, a complex of vitamins B1, B6, PP) Fertilizer stimulates the development of the root system, has anti-stress properties, and stimulates photosynthetic activity.

Nutrimyr 4-4-10 (Manufacturer - ITALPOLLINA Group, Italy) - an organomineral fertilizer containing nitrogen, phosphorus, potassium, manganese, zinc, boron, molybdenum, biologically active substances (a complex of amino acids and peptides). The use of Nutrimir 4-4-10 promotes optimal ripening and improving the fruit quality of vegetable crops, increases stress resistance of plants, contributes to better absorption and assimilation of nutrients.

Quick-Link (Manufacturer - ITALPOLLINA Group, Italy) - organomineral fertilizer for top-dressing, which includes copper, iron, manganese, molybdenum, zinc, biologically active substances - amino acids, peptides, lignosulfonates, organic substances. Quick-Link enhances the absorption of macroelements by plants, stress resistance of plants, promotes the development of the root system, activates the development of trichoderma and mycorrhizal fungi.

Scheme of experience: 1 - Control (background); 2 - Background + 5AP; 3 Background + Maxifol Rutfarm; 4 - Background + Nutrimir 4-4-10; 5 - Background + 
Quick-Link. In the experiment, foliar top-dressing Nutrimir 4-4-10 (5 ml/ha) was carried out, root top-dressing: 5AP (5.5-6.0 1/ha), Quick-Link (3-4 1/ha), Maxifol Ruthpharm (4.0$4.5 \mathrm{l} / \mathrm{ha}$ ); the first top-dressing - in the flowering phase of the first brush, subsequent with an interval of 14 days until the end of the growing season.

The production experience was built according to the method of organized repetition, the placement of repetitions is continuous, the arrangement of plots is multi-tiered, the options within the repetition are randomized. The total plot area is $14 \mathrm{~m}^{2}$, the plot width is $1.4 \mathrm{~m}$, the length is $10 \mathrm{~m}$, and the plot area is $14 \mathrm{~m}^{2}$. Observations, counts, chemical analysis of plants was carried out in accordance with generally accepted methods and recommendations. Laboratory analyzes were performed on the basis of the university's agrochemical laboratory.

\section{Results}

\subsection{Vegetative and generative organs of tomato}

The growth of leaf mass, the growth of the stem, the filling of the fruits of tomato plants in production experiments, especially in greenhouse ground conditions, are important indicators characterizing the varieties (hybrids) studied and agricultural practices. The entry of tomato into various phases of development is explained by internal processes occurring in the plant. In this regard, the plant has special requirements for environmental conditions, especially for mineral nutrition.

The growth period of tomato plants includes various stages of development: rooting of seedlings, vegetative growth, flowering, development and ripening of fruits. All stages differ in needs for growing conditions and nutrients. At the stage of rooting seedlings, it is necessary to focus on the growth of the root system and the formation of the initial aerial organs of the plant. Vegetative growth lasts for the first 40-45 days, after which the fruits begin to develop. After vegetative growth for four weeks, rapid growth is observed when the plant blooms and forms fruits. After 70 days, vegetative growth practically stops and there is no accumulation of dry matter in the stems and leaves.

The formation of the vegetative and generative organs of the tomato and the "strength of the plant" in a greenhouse ground are influenced by the microclimate, agricultural techniques, as well as the biological potential of the hybrid (cultivar). Under the concept of "strength of the plant" agronomists understand the ability of a culture to grow under stressful conditions. The microclimate and various processes that occur in the plant have an important influence on this indicator. With an imbalance of any of the factors, this is visually manifested on the plant. The main processes that determine the "strength of the plant" of tomato are: growth, photosynthesis, transpiration and assimilant transport. Plant productivity depends on mineral nutrition. The use of organomineral fertilizers containing biologically active substances is highly effective in greenhouse soil. Organomineral fertilizers were introduced into the nutritional scheme with an interval of 14 days, therefore, the decisive effect on plants was exerted not by their macro- and microelements, but biologically active substances with growth-promoting and anti-stress properties, which is confirmed by research data. Fertilizing with organomineral fertilizers stimulated the development of the root system, maintaining a balanced ratio of vegetative mass and total load of fruits.

The research objectives included the study of the formation of vegetative organs and fruits. In the experiment, tomato Sherami F1 of indeterminate growth type was grown. Indeterminate type tomatoes are the highest of all other types. The growth of indeterminate tomatoes is unlimited and the length of the main stem can reach $10 \mathrm{~m}$ or more. A tomato of 
this type of growth forms a large number of generative buds, their fruits ripen gradually, and up to 40-50 brushes can form on one bush. Indeterminate tomatoes are grown in greenhouse ground and are characterized by a long development of the vegetative part compared to hybrids that have limited growth. In addition, the Sherami F1 hybrid belongs to early tomatoes and forms a leaf apparatus in a relatively short time.

In the experiment, biologically active substances were used as part of organomineral fertilizers that intensified metabolic processes in the plant, as a result, the average growth of plants per week was higher compared to the control. The average growth of tomato per week with the use of Nutrimir 4-4-10 fertilizer was $18.6 \mathrm{~cm}$, which exceeded the control by $1.7 \mathrm{~cm}$. Top-dressing of plant leaves with Maxifol Rutfarm significantly increased the average growth per week compared to the control by $2.8 \mathrm{~cm}$. When using $5 \mathrm{AP}$ fertilizer, the average increase per week was significantly higher than in the control by $3.4 \mathrm{~cm}$. The greatest increase was obtained with Quick-Link $-21.2 \mathrm{~cm}$, the difference compared with the control was $4.3 \mathrm{~cm}$, relative to the top-dressing with Maxifol Rutfarm, Nutrimir 4-4-10 and $5 \mathrm{AP}-0.9-2.6 \mathrm{~cm}$ (Table 1).

Table 1. The effect of organomineral fertilizers on the vegetative growth of tomato

\begin{tabular}{|l|c|l|l|}
\hline Option & $\begin{array}{l}\text { Average growth } \\
\text { per week, cm }\end{array}$ & $\begin{array}{l}\text { Plant } \\
\text { height, cm }\end{array}$ & $\begin{array}{l}\text { The number of } \\
\text { leaves, pieces }\end{array}$ \\
\hline Control (background) & 16.9 & 745.9 & 19.2 \\
\hline Background + 5AP & 20.3 & 888.1 & 23.5 \\
\hline $\begin{array}{l}\text { Background + Maxifol } \\
\text { Rutfarm }\end{array}$ & 19.7 & 872.5 & 22.7 \\
\hline $\begin{array}{l}\text { Background + Nutrimir 4- } \\
\text { 4-10 }\end{array}$ & 18.6 & 826.2 & 21.5 \\
\hline Background + Quick-Link & 21.2 & 906.5 & 24.5 \\
\hline $\begin{array}{l}\text { Least significant difference } \\
\text { for 5\% significance level }\end{array}$ & 0.8 & 17.4 & 0.6 \\
\hline
\end{tabular}

Depending on the average growth per week, the height of tomato plants varied: the dynamics of changes relative to the control was similar. The smallest plant height was obtained in the control $-745.9 \mathrm{~cm}$. When using organomineral fertilizers, the height of tomato plants increased significantly relative to the control by $80.3-160.6 \mathrm{~cm}$. The highest plants were obtained as a result of top-dressing with Quick-Link fertilizer $-906.5 \mathrm{~cm}$, the difference compared to the control amounted to $160.6 \mathrm{~cm}$.

The crop productivity depends on the size of the leaf apparatus: the number of leaves and their area. In the experiment, the total number of leaves formed on one plant over the entire growing period was determined. High efficiency in this regard was noted during root top-dressing with fertilizers 5AP and Quick-Link - 23.5 and 24.5 pieces, respectively, the difference regarding control and use of Maxifol Rutfarm and Nutrimir 4-4-10 was 0.8-5.3 pieces. As a result of top-dressing with fertilizers Maxifol Rutfarm and Nutrimir 4-4-10 the number of leaves was higher than in the control by 3.5 and 2.3 pieces, respectively.

The beginning of flowering and fruit formation depends on the variety, environmental conditions, agricultural practices. This period begins 20-40 days after transplantation and lasts throughout the remainder of the plant growth cycle. After flowering and fruit setting, fruit development and growth begins. During the period of fruit development, a high amount of dry matter accumulates in them. Fruits ripen on average 50-80 days after transplanting seedlings. Harvesting lasts continuously and is carried out as the fruit ripens.

The formation of fruits determines the total productivity of tomato. According to morphological characteristics, a tomato fruit is a fleshy berry of various colors. The mass of the tomato fruit can vary from $1 \mathrm{~g}$ (in wild forms) to $500 \mathrm{~g}$ or more in the most large-fruited 
varieties. Depending on the shape, tomato fruits are flat, round, oval, pear-shaped, elongated-cylindrical. The surface of tomato fruits is smooth, ribbed, dull or glossy. Coloring can be varied.

Tomato productivity at the end of the growing period is determined by the formed and ripened fruits, their total mass. Depending on the size and shape of the fruit, tomatoes are divided into cherry-shaped, or cherry-tomatoes, round, or ordinary - the most popular among the population of Russia, there are also beef-tomatoes - large and very large. The studied hybrid of tomato Sherami F1 belongs to the group of small-fruited tomatoes, varieties of cherry that form long brushes, the quantity of which depended on the crop productivity.

By the end of the turnover, the number of brushes in the experimental plants of tomato Sherami F1 varied within 35.2-40.8 pieces. When using organomineral fertilizers, the number of tomato brushes increased relative to the control. As a result of top-dressing plants with Maxifol Rutfarm the number of brushes collected was greater than in the control by 3.2 pieces. The use of Nutrimir 4-4-10 fertilizer contributed to a significant increase in the number of brushes collected relative to the control by 1.7 pieces. When topdressing plants with 5AP and Quick-Link, the number of brushes collected was significantly greater than in the control by 5.6 and 4.5 pieces, respectively, the difference between these options was insignificant (Table 2).

Table 2. The effect of organomineral fertilizers on the formation of tomato fruits

\begin{tabular}{|l|l|l|l|l|}
\hline \multirow{2}{*}{ Option } & \multicolumn{2}{|l|}{$\begin{array}{l}\text { The number of collected } \\
\text { brushes of tomato, pieces }\end{array}$} & \multicolumn{2}{|l|}{$\begin{array}{l}\text { The average weight of the } \\
\text { tomato fruit, g }\end{array}$} \\
\cline { 2 - 5 } & average & $+/$ - to control & average & + - to control \\
\hline Control (background) & 35.2 & - & 13.2 & - \\
\hline Background +5AP & 40.8 & 5.6 & 15.4 & 2.2 \\
\hline $\begin{array}{l}\text { Background } \\
\text { Maxifol Rutfarm }\end{array}$ & 38.4 & 3.2 & 13.8 & 0.6 \\
\hline $\begin{array}{l}\text { Background } \\
\text { Nutrimir 4-4-10 }\end{array}$ & 36.9 & 1.7 & 14.1 & 0.9 \\
\hline $\begin{array}{l}\text { Background + Quick- } \\
\text { Link }\end{array}$ & 39.7 & 4.5 & 14.9 & 1.7 \\
\hline $\begin{array}{l}\text { Least significant } \\
\text { difference for 5 \% } \\
\text { significance level }\end{array}$ & 0.9 & & 0.4 & \\
\hline
\end{tabular}

Tomato Sherami F1 forms small round-shaped fruits for piece harvesting, which are distinguished by high density and resistance to cracking. When using biologically active substances in organomineral fertilizers, the average weight of the tomato fruit increased by 0.6-2.2 g compared to the control. The difference in the average weight of the fruit when using Maxifol Rutfarm and Nutrimir 4-4-10 was not significant -0.3 g. Plant treatment of tomato by fertilizer Quick-Link contributed to an increase in the average weight of the fruit relative to the control by $2.2 \mathrm{~g}$. The largest average weight of the fruit was obtained as a result of root top-dressing with $5 \mathrm{AP}$ fertilizer $-15.4 \mathrm{~g}$, which exceeded the control by $2.2 \mathrm{~g}$.

\subsection{Chemical composition of plants}

The use of nutrients in an optimal amount contributing to the rapid formation of a vegetative mass has a positive effect on the productivity of tomato fruits. Nutrients that are absorbed by the vegetative organs of plants are used in the formation of fruits. Understanding the chemical composition of plants allows you to more fully reveal the 
properties of the formation of crop yields, including tomato. The application of this knowledge in practice is used in the development of a rational nutrition system, assessment of nutritional conditions and yield quality. One of the ways to optimize the mineral nutrition of crops in intensive growing technologies is to provide crops additionally with nutrients through the leaves and root system. In our studies, using both leaf and root topdressings of tomato, we studied the effect of biologically active substances in organomineral fertilizers on the content of essential nutrients in leaves and fruits. As a result of experiments, it was found that the tomato responded well to the use of fertilizing top-dressings.

A coconut substrate was used to grow the tomato, which served as an alternative to the soil, and complete mineral nutrition of the culture was carried out through drip irrigation. Nutrient solutions with a certain balanced ratio of nutrients, levels of acidity and electrical conductivity were the control and background for all variants of the experiment. For the preparation of nutrient solutions, water-soluble fertilizers (potassium, magnesium, calcium nitrate, complex fertilizers, etc.) were used, which had a decisive influence on the chemical composition of all organs of the tomato plant. Compared with the main fertilizers used in nutrient solutions, organomineral fertilizers, which were used in the experiment in the form of root and leaf top-dressings, did not significantly affect the change in the number of nutrients in the leaves and fruits of tomato plants, but changes were noted. An increase in nutrient elements in tomato leaves suggests that the use of organomineral fertilizers contributed to the intensification of metabolic processes in plants. The greatest efficiency in the accumulation of nutrients in plant tissues was noted with the use of root top-dressing (Table 3).

Table 3. The effect of organomineral fertilizers on the content of nutrients in tomato leaves, $\%$ to dry weight

\begin{tabular}{|c|c|c|c|c|c|c|}
\hline \multirow{2}{*}{ Option } & \multicolumn{2}{|c|}{$\mathrm{N}_{\text {total }}$} & \multicolumn{2}{c|}{$\mathrm{P}_{2} \mathrm{O}_{5}$} & \multicolumn{2}{c|}{$\mathrm{K}_{2} \mathrm{O}$} \\
\cline { 2 - 7 } & average & $\begin{array}{c}+/ \text { - to } \\
\text { control }\end{array}$ & average & $\begin{array}{c}+/ \text { - to } \\
\text { control }\end{array}$ & average & $\begin{array}{c}+/ \text { - to } \\
\text { control }\end{array}$ \\
\hline Control (background) & 4.8 & - & 0.62 & - & 4.6 & - \\
\hline Background + 5AP & 5.3 & 0.5 & 0.79 & 0.17 & 5.4 & 0.8 \\
\hline $\begin{array}{c}\text { Background + Maxifol } \\
\text { Rutfarm }\end{array}$ & 5.1 & 0.3 & 0.69 & 0.07 & 4.7 & 0.1 \\
\hline $\begin{array}{c}\text { Background + Nutrimir 4- } \\
\text { 4-10 }\end{array}$ & 5.1 & 0.3 & 0.70 & 0.08 & 4.8 & 0.2 \\
\hline $\begin{array}{c}\text { Background + Quick- } \\
\text { Link }\end{array}$ & 5.4 & 0.6 & 0.84 & 0.22 & 5.6 & 1.0 \\
\hline $\begin{array}{c}\text { Least significant } \\
\text { difference for 5 \% } \\
\text { significance level }\end{array}$ & 0.1 & & 0.04 & & 0.3 & \\
\hline
\end{tabular}

Compared to other elements of mineral nutrition, nitrogen is a powerful growth regulator, despite the fact that this element does not belong to hormonal substances [10]. Nitrogen in the composition of fertilizers plays the role of an important building material of plants involved in the synthesis of proteins. Proteins consisting of amino acids are the main constituent of protoplasm. In addition, nitrogen is part of the molecules of vitamins, chlorophyll, alkaloids.

As a result of studies, it was found that the nitrogen content in tomato leaves when using organomineral fertilizers increased in relation to the control by $0.3-0.6 \%$ to dry weight. When using Maxifol Rutfarm and Nutrimir 4-4-10, the nitrogen content in the leaves increased significantly compared to the control by $0.3 \%$ to dry weight. Treatment of tomato plants with $5 \mathrm{AP}$ fertilizer contributed to an increase in the total nitrogen in tomato 
leaves relative to the control by $0.5 \%$ to dry weight, with Quick-Link fertilizer by $0.6 \%$ to dry weight. The difference in the amount of nitrogen in tomato leaves with the use of agrochemicals 5AP and Quick-Link was insignificant $-0.1 \%$ to dry weight.

Phosphorus plays an important role in plant metabolism. Phosphorus contributes to the formation of a strong organism, intensifies the synthesis of important compounds (proteins, carbohydrates, fats, enzymes), and increases plant resistance to stress [11]. In the first stages of development, a tomato culture requires a high amount of phosphorus.

The use of organomineral fertilizers contributed to an increase in the phosphorus content in tomato leaves relative to the control by $0.07-0.22 \%$ to dry weight. When using fertilizers Maxifol Rutfarm and Nutrimir 4-4-10, the phosphorus content in tomato leaves was significantly higher than in the control at 0.07 and $0.08 \%$ to dry weight. Root topdressing of tomato with $5 \mathrm{AP}$ contributed to a significant increase in phosphorus relative to the control by $0.17 \%$ to dry weight. During root top-dressing of tomato plants with QuickLink, the phosphorus content was $0.22 \%$ more than the dry weight in the control. The greatest change in the amount of phosphorus in the leaves was noted with Quick-Link, which contributes to the development of additional volume of the root system of the plant.

Macronutrient potassium in the plant cell sap is contained in an amount of about $80 \%$, in an absorbed state in an exchange form - $20 \%$, in mitochondria non-exchangeally - about $1 \%$. Potash fertilizers play a key role in the formation of productivity and quality of tomato fruits [12].

The amount of potassium in tomato leaves after top-dressing with the studied fertilizers increased relative to the control by $0.1-1.0 \%$ to dry weight. When using Maxifol Rutfarm and Nutrimir 4-4-10, the potassium content in tomato leaves was not significantly higher than in the control. The introduction of organomineral fertilizer 5AP into the tomato nutrition scheme contributed to a significant increase in potassium in tomato leaves relative to the control by $0.8 \%$ to dry weight. The greatest amount of potassium in tomato leaves was when processing plants with Quick-Link - 5.6\% to dry weight.

Changes in the increase in the content of nitrogen, phosphorus, and potassium in mature tomato fruits as a result of the use of organomineral fertilizers were similar to changes in the leaves. Top-dressing with organomineral fertilizers contributed to an increase in the nitrogen content in tomato fruits compared with the control by $0.2-0.6 \%$ to dry weight, phosphorus - by $0.06-0.19 \%$ to dry weight, potassium - by $0.4-0.9 \%$ to dry weight. The difference in the number of nutrients in tomato fruits between the application of Maxifol Rutfarm and Nutrimir 4-4-10 was insignificant (Table 4).

Table 4. The effect of organomineral fertilizers on the content of nutrients in tomato fruits, $\%$ to dry weight

\begin{tabular}{|c|c|c|c|c|c|c|}
\hline \multirow{2}{*}{ Option } & \multicolumn{2}{|c|}{$\mathrm{N}_{\text {total }}$} & \multicolumn{2}{c|}{$\mathrm{P}_{2} \mathrm{O}_{5}$} & \multicolumn{2}{c|}{$\mathrm{K}_{2} \mathrm{O}$} \\
\cline { 2 - 7 } & average & $\begin{array}{c}+/- \text { to } \\
\text { control }\end{array}$ & average & $\begin{array}{c}+/ \text { - to } \\
\text { control }\end{array}$ & average & $\begin{array}{c}+ \text { +- to } \\
\text { control }\end{array}$ \\
\hline $\begin{array}{c}\text { Control } \\
\text { (background) }\end{array}$ & 4.2 & - & 0.44 & - & 4.1 & - \\
\hline Background + 5AP & 4.6 & 0.4 & 0.60 & 0.16 & 4.7 & 0,6 \\
\hline $\begin{array}{c}\text { Background + } \\
\text { Maxifol Rutfarm }\end{array}$ & 4.5 & 0.3 & 0.50 & 0.06 & 4.5 & 0,4 \\
\hline $\begin{array}{c}\text { Background + } \\
\text { Nutrimir 4-4-10 }\end{array}$ & 4.4 & 0.2 & 0.52 & 0.08 & 4.6 & 0,5 \\
\hline $\begin{array}{c}\text { Background + } \\
\text { Quick-Link }\end{array}$ & 4.8 & 0.6 & 0.63 & 0.19 & 5.0 & 0,9 \\
\hline $\begin{array}{c}\text { Least significant } \\
\text { difference for 5\% } \\
\text { significance level }\end{array}$ & 0.2 & & 0.03 & & 0.3 & \\
\hline
\end{tabular}


As a result of the use of $5 \mathrm{AP}$ fertilizer, the nitrogen content in tomato fruits was higher than in the control by $0.4 \%$ to dry weight, phosphorus by $0.16 \%$ to dry weight, and potassium by $0.6 \%$ to dry weight. Most macroelements in tomato fruits accumulated during the top-dressing of tomato with Quick-Link and significantly exceeded the control indices: nitrogen - by $0.6 \%$ to dry weight, phosphorus - by 0.19 , potassium - by 0.9 .

\subsection{Biochemical composition of tomato fruits}

The quality of tomato fruits is a complex concept and is determined by the biochemical composition (sugars, vitamins), taste, pulp structure, fruit shape, size and color. A goodtasting tomato has a high content of extractives - sugars, mineral salts, acids, vitamins and pectin. The taste of tomato fruits does not improve with a low amount of acids; processed products from such tomatoes are poorly preserved. High sugar content in combination with high acidity does not negatively affect the taste of the fruit.

Tomatoes, like other crops, accumulate nutrients throughout the growing season. Most of them are found in fresh, just harvested vegetables, which are stored in favorable conditions. The accumulation of nutrients depends on many factors - variety (hybrid), soil, climate, water regime, methods of caring for plants and nutritional conditions, which is confirmed by the work of scientists $[13,14]$. Studies have found that when top-dressing by organomineral fertilizers, the biochemical composition of tomato fruits improved relative to the control.

The dry matter content is one of the main quality indicators of tomato fruits. The results of laboratory tests established that the dry matter content in tomato fruits in the experiment was in the range of 7.7-8.7\%. The dry matter content in tomato fruits when using Maxifol Rutfarm, Nutrimir 4-4-10 and 5AP was significantly higher than in the control by $0.5,0.3$ and $0.8 \%$, respectively. The largest amount of dry matter was accumulated in tomato fruits during root top-dressing with Quick-Link $-8.7 \%$, which significantly exceeded the control variant by $1.0 \%$ (Table 5 ).

Table 5. The effect of organomineral fertilizers on the biochemical composition of tomato fruits

\begin{tabular}{|c|c|c|c|c|c|c|}
\hline \multirow{2}{*}{ Option } & \multicolumn{2}{|c|}{ Dry matter, \% } & \multicolumn{2}{c|}{ Sugar, \% } & \multicolumn{2}{c|}{ Nitrogen, $\mathrm{mg} / \mathrm{kg}$} \\
\cline { 2 - 7 } & average & $\begin{array}{c}+/ \text { - to } \\
\text { control }\end{array}$ & average & $\begin{array}{c}+/ \text { - to } \\
\text { control }\end{array}$ & average & $\begin{array}{c}+/ \text { - to } \\
\text { control }\end{array}$ \\
\hline Control (background) & 7.7 & - & 4.6 & - & 184 & - \\
\hline Background + 5AP & 8.5 & 0.8 & 5.4 & 0.8 & 210 & 26 \\
\hline $\begin{array}{c}\text { Background + } \\
\text { Maxifol Rutfarm }\end{array}$ & 8.2 & 0.5 & 5.0 & 0.4 & 195 & 11 \\
\hline $\begin{array}{c}\text { Background + } \\
\text { Nutrimir 4-4-10 }\end{array}$ & 8.0 & 0.3 & 4.8 & 0.2 & 190 & 6 \\
\hline $\begin{array}{c}\text { Background + Quick- } \\
\text { Link }\end{array}$ & 8.7 & 1.0 & 5.8 & 1.2 & 212 & 28 \\
\hline $\begin{array}{c}\text { Least significant } \\
\text { difference for 5 \% } \\
\text { significance level }\end{array}$ & 0.2 & & 0.3 & & 5 & \\
\hline
\end{tabular}

Sugar in tomato fruits is the main component of dry matter. The sugar content in tomato fruits varied depending on the use of organomineral fertilizers in the range of 4.6-5.8\%. The amount of sugars in tomato fruits when using Nutrimir 4-4-10 was insignificantly higher than in the control by $0.2 \%$, and less than when using Maxifol Rutfarm by $0.2 \%$. When $5 \mathrm{AP}$ fertilizer was added to the nutrition scheme, the sugar content in tomato fruits was $0.8 \%$ higher compared to the control. Most sugars accumulated in tomato fruits during the top-dressing with Quick-Link - 5.7\%, which was significantly more than in the control by 
$1.2 \%$.

The maximum permissible concentrations are established for the content of nitrate compounds in fruits and vegetables products and feed in Russia. For tomato fruits grown in greenhouses, the maximum permissible concentration of nitrates is $300 \mathrm{mg} / \mathrm{kg}$. Laboratory analyzes found that the amount of nitrates in tomato fruits turned out to be less than the maximum permissible concentration by $88-116 \mathrm{mg} / \mathrm{kg}$, the values varied depending on the applied organomineral fertilizer. The least nitrates in tomato fruits were noted in the control variant $-184 \mathrm{mg} / \mathrm{kg}$. The highest nitrate content was obtained in tomato fruits when treating plants with $5 \mathrm{AP}$ fertilizer $-212 \mathrm{mg} / \mathrm{kg}$, the difference relative to other experimental options was $2-28 \mathrm{mg} / \mathrm{kg}$.

\subsection{Tomato productivity}

The main indicator of crop efficiency is productivity, which characterizes the economic value of the cultivated variety or hybrid, which have a different genetic yield potential. The process of tomato fruit formation is long, in connection with this they are harvested as they ripen. At the time of harvesting, the fruits are picked only from those plants on which the fruits have reached technical ripeness.

For the highest possible yields of vegetable crops, it is necessary to use highly productive varieties (hybrids) and a balanced nutrition scheme. In the experiment, the tomato productivity varied between $26.0-29.7 \mathrm{~kg} / \mathrm{m} 2$. The use of top-dressing for vegetable crop leaves is an effective method of increasing productivity [15]. Fertilizer Nutrimir 4-4-10 was used as top-dressing for leaves. The treatment of tomato plants with Maxifol Ruthpharm fertilizer stimulated tomato bloom, increased plant resistance to stress, as a result, the productivity significantly exceeded the control value by $1.1 \mathrm{~kg} / \mathrm{m} 2$, and was less than 0.5 $2.6 \mathrm{~kg} / \mathrm{m} 2$ in comparison with the 5AP, Maxifol Rutfarm and Quick-Link versions. Fertilizers 5AP, Maxifol Rutfarm and Quick Link were used as root top-dressings. The treatment of plants with Maxifol Rutfarm fertilizer, containing a complex of biologically active substances, contributed to an increase in tomato productivity relative to the control by $1.6 \mathrm{~kg} / \mathrm{m} 2$ (Table 6$)$.

Table 6. The effect of organomineral fertilizers on tomato productivity, $\mathrm{kg} / \mathrm{m} 2$

\begin{tabular}{|l|l|l|}
\hline Option & Average & + /- to control \\
\hline Control (background) & 26.0 & - \\
\hline Background + 5AP & 29.7 & 2.7 \\
\hline Background + Maxifol Rutfarm & 27.6 & 1.6 \\
\hline Background + Nutrimir 4-4-10 & 27.1 & 1.1 \\
\hline Background + Quick-Link & 29.3 & 2.3 \\
\hline $\begin{array}{l}\text { Least significant difference for 5\% } \\
\text { significance level }\end{array}$ & 0.7 & \\
\hline
\end{tabular}

The productivity of tomato when applying Quick-Link was significantly higher than in the control and use of Maxifol Rutfarm, Nutrimir 4-4-10 at 1.7-2.3 kg/m². The highest productivity was obtained during tomato cultivation with the addition of root top-dressing $5 \mathrm{AP}-29.7 \mathrm{~kg} / \mathrm{m}^{2}$, the difference with respect to control and use of Maxifol Rutfarm, Nutrimir 4-4-10 was significant and amounted to $2.1-3.7 \mathrm{~kg} / \mathrm{m}^{2}$, compared to Quick-Link is insignificant $-0.4 \mathrm{~kg} / \mathrm{m}^{2}$. 


\section{Discussion}

The research results confirm that the use of biologically active substances in organomineral fertilizers when growing tomatoes in winter greenhouses increases the intensity of physiological processes and the productivity of the culture increases.

The highest growth and the highest plants were obtained with Quick-Fertilizer fertilizer: the indicators exceeded the control by $4.3 \mathrm{~cm}$ and $160.6 \mathrm{~cm}$, respectively. Most of the leaves on one plant were noted during root top-dressing with organomineral fertilizers 5AP and Quick-Link - 24.5 and 23.7 pieces, respectively, the difference with respect to control and use of Maxifol Rutfarm and Nutrimir 4-4-10 was 0.8-5.3 pieces.

Most of the harvested brushes and the largest fruits in the experiment were obtained using 5AP fertilizer: the indicators were significantly greater than in the control by 5.6 pieces and $2.2 \mathrm{~g}$, respectively.

Top-dressing with organomineral fertilizers contributed to a better assimilation of macroelements by tomato plants. When using Maxifol Rutpharm, Nutrimir 4-4-10, 5AP and Quick-Link, the nitrogen content in the leaves was higher than in the control by 0.30.6 , phosphorus by $0.07-0.22$, potassium by $0.1-1.0 \%$ to dry mass. When applying topdressing, the nitrogen content in tomato fruits increased in comparison with the control by $0.2-0.6 \%$ to dry weight, phosphorus by $0.06-0.19$, and potassium by $0.4-0.9$. The highest rates were noted when using Quick-Link fertilizer.

The use of biologically active substances in the composition of organomineral fertilizers contributed to the improvement of the qualitative composition of tomato fruits. Most dry matter and sugars in tomato fruits accumulated during the top-dressing of plants with Quick-Link and were significantly higher than the control by $1.0 \%$ and $1.2 \%$, respectively. The nitrate content in tomato fruits was within the maximum permissible concentration. The least nitrates were obtained in the control $-184 \mathrm{mg} / \mathrm{kg}$, the difference relative to other experimental options was $2-28 \mathrm{mg} / \mathrm{kg}$.

The highest productivity of cherry tomato Sherami F1 in extended turnover was obtained with the use of organomineral fertilizer $5 \mathrm{AP}-29.7 \mathrm{~kg} / \mathrm{m}^{2}$, which was higher than in the control, with the use of Maxifol Rutfarm, Nutrimir 4-4-10 and Quick Link the productivity was higher than in the control by $0.4-3.7 \mathrm{~kg} / \mathrm{m}^{2}$.

\section{References}

1. M.J. Zarei, N. Kazemi, A. Marzban, J. of the Saudi Society of Agricultural Sci., 18 (3), 249-255 (2019). doi: 10.1016/j.jssas.2017.07.001

2. W.N. Ochilo, G.N. Nyamasyo, D. Kilalo, W. Otieno, M. Otipa, F. Chege, T. Karanja, E.K. Lingeera, Sci. African, 2, e00014 (2019). doi:10.1016/j.sciaf.2018.e00014

3. T. Groher, S. Röhlen-Schmittgen, A. Fiebig, G. Noga, M. Hunsche, Sci. Horticulturae, 250, 154-158 (2019). doi: 10.1016/j.scienta.2019.02.046

4. J. Lu, G. Shao, J. Cui, X. Wang, L. Keabetswe, Agricultural Water Management, 222, 301-312 (2019). doi: 10.1016/j.agwat.2019.06.008

5. J.V. Kolomiets, I.P. Grygoryuk, L.M. Butsenko, Annals of Agrarian Sci., 15 (2), 213 216 (2017). doi: 10.1016/j.aasci.2017.05.010

6. K. Muthu-Pandian Chanthini, S. Senthil-Nathan, V. Stanley-Raja, A. Thanigaivel, S. Karthi, H. Sivanesh, N. S. Sundar, R. Palanikani, R. Soranam, Biocatalysis and Agricultural Biotechnology, 20, 101190 (2019). doi: 10.1016/j.bcab.2019.101190

7. Y. Li, Y. Sun, S. Liao, G. Zou, T. Zhao, Y. Chen, J. Yang, L. Zhang, Agricultural Water Management, 186, 139-146 (2017). doi: 10.1016/j.agwat.2017.02.006 
8. J. Guo, R. Zhou, X. Ren, H. Jia, L. Hua, H. Xu, X. Lv, J. Zhao, T. We, Ecotoxicology and Environmental Saf., 157, 491-496 (2018). doi: 10.1016/j.ecoenv.2018.04.010

9. Z. Zhu, Y. Zhang, J. Liu, Y. Chen, X. Zhang, Food Chem., 252, 9-15 (2018). doi: 10.1016/j.foodchem.2018.01.064

10. Y.-D. Du, X.-B. Gu, J.-W. Wang, W.-Q. Niu, Sci. of The Total Environ., 668, 11561164 (2019). doi: 10.1016/j.scitotenv.2019.03.098

11. N. Naz, I. Khan, B. Gul, G. Ayub, M. Shuaib, Acta Ecologica Sinica, 39 (1), 30-35 (2019). doi: 10.1016/j.chnaes.2018.06.004

12. B.P. Chapagain, Z. Wiesman, Scientia Horticulturae, 99 (3-4) (2004). doi: 10.1016/S0304-4238(03)00109-2

13. T. Kinoshita, H. Yamazaki, K. Inamoto, H. Yamazaki, Scientia Horticulturae, 202, $17-$ 24 (2016). doi: 10.1016/j.scienta.2016.02.019

14. M. Watanabe, Y. Ohta, S. Licang, N. Motoyama, J. Kikuchi, Food Chemistry, 169 (2015). doi: 10.1016/j.foodchem.2014.07.155

15. Q. Zhu, M. Zhang, Q. Ma, Scientia Horticulturae, 143, 109-114 (2012). doi: 10.1016/j.scienta.2012.06.008 